\title{
Looking for Agency in Transnational Refugee Trajectories during the Second World War
}

\author{
ROSA DE JONG* \\ E-mail: r.dejong@uva.nl
}

Eric T. Jennings. Escape from Vichy: The Refugee Exodus to the French Caribbean. Cambridge, Mass.: Harvard University Press, 2018. 308 pages. ISBN: 9780674983380, \$36.

Megan Koreman. The Escape Line: How the Ordinary Heroes of Dutch-Paris Resisted the Nazi Occupation of Western Europe. New York: Oxford University Press, 2018. 410 pages. 9780190662271, \$29,95.

Joanna Newman. Nearly the New World: The British West Indies and the Flight from Nazism, 1933-1945. New York: Berghahn Books, 2019. 306 pages. 9781789206494, \$29,95.

The authors of three recent monographs, The Escape Line, Escape from Vichy, and Nearly the New World, highlight in particular the relevance of transnational refugee and resistance networks. These books shed new light on the trajectories of refugees through war-torn Europe and their routes out of it. Megan Koreman displays in The Escape Line the relevance of researching one line of resistance functioning in several countries and thereby shifts from the common nationalistic approach in resistance research. In Escape from Vichy Eric Jennings researches the government-endorsed flight route between Marseille and Martinique and explores the lasting impact of encounters between refugees and Caribbean Negritude thinkers. Joanna Newman explores the mainly Jewish refugees who found shelter in the British West Indies, with a focus on the role of aid organisations in this flight.

Keywords: World War II, transnational history, refugees, West Indies, resistance networks

Histories of World War II have typically been written within a framework of perspectives bounded by the borders of a single country or region, and refugee studies of this period focussed mainly on Western trajectories, in particular on refugees who fled from Europe 
to the United States of America. What new light can be shed on seemingly well-tread historical ground by taking a transnational perspective, as several recent works in World War II studies have done? The authors of three recent monographs, Escape from Vichy, The Escape Line, and Nearly the New World, highlight in particular the relevance of transnational refugee and resistance networks. These relevant books research the trajectories of mainly Jewish refugees through war-torn Europe and their routes out of it.

\section{The Broader Caribbean Field}

Escape from Vichy, The Escape Line, and Nearly the New World contribute to the study of resistance from a transnational perspective. Comparing these three works demonstrates both the challenges and the important contributions of considering the events and effects of World War II in a transnational, and in two cases a Caribbean, perspective. All three of these monographs face intertwined challenges regarding the array of sources and perspectives used, and more specifically, the agency each author is able to attribute to the individuals who populate the histories she or he sets out to recount and analyse. Taken together, these works raise critical questions about how to reframe what has long been considered a field of European historiography as a transnational history with resonating global effects.

A focus on the Caribbean experience will highlight this transnational turn. The academic study of the arrival of World War II refugees in the Caribbean is an emerging topic. One of the first publications solely about Second World War refugees in the Caribbean was published in 2008 by Marion Kaplan. ${ }^{1}$ This richly illustrated book on refugees in the Dominican Republic is referenced in Newman's epilogue. The Dominican case is very different from the situation in the French, British, or Dutch Caribbean because the refugees were invited by Dominican dictator Rafael Trujillo and, in return, had to commit to build their own settlement and farm the land. Refugees from Nazism in Cuba are better researched and do appear more often in scholarly work than refugees in other Caribbean countries. Robert M. Levine had featured the refugees in Cuba as early as $1993 .^{2}$ They were notable for several reasons: the large number of refugees residing on the island; the famous case of the German refugee ship St. Louis being denied entrance to Havana, which drew international attention to Cuba; and the many refugees in Cuba who went to the United States after the war and left testimonies.

Although the British West Indies are less well studied, Joanna Newman's Nearly the New World is not the first book about the experiences of the Second World War refugees there. Diana Cooper-Clark published Dreams of Re-Creation in Jamaica in 2017. ${ }^{3}$ Cooper-Clark's publication, primarily based on oral histories and memoires, is centred around the Gibraltar Camp where the refugees were interned and sheds light on their day-to-day life in Jamaica. Both authors describe how the internment camp was structured, some maps are included, and Cooper-Clark explains the extent of their freedom to leave the camp. Her book is richly illustrated and articulates many personal 
experiences of the flight and internment; this publication however would have benefitted from Newman's extensive context and background. Jennings's Escape from Vichy is a pioneering work for the Francophone Caribbean; previously other monographs researching this period had focussed on more traditional topics such as the French (overseas) maritime strategy and colonial power shifts during the war.

For the Dutch Caribbean context of the Second World War period, very little literature is available, and even less in English. Most publications do not go beyond mentioning the arrival of the refugees. The very first to mention the refugees, be it in only one paragraph, was historian Loe de Jong in his incredible life's work, Het Koninkrijk der Nederlanden in de Tweede Wereldoorlog. ${ }^{4}$ A popular non-academic booklet published by the Dutch Resistance Museum in 2004, Wereldoorlog in de West, edited by Liesbeth van der Horst, briefly deals with the flight and the arrival of Jewish refugees in the Dutch Caribbean colonies. ${ }^{5}$ The chapter about the refugees, however, contains many small and some more serious mistakes. Jeannette van Ditzhuijzen's A Shtetl under the Sun and Ben Scholtens's Suriname tijdens de Tweede Wereldoorlog also mention European war refugees during the Second World War in Curaçao and Suriname. ${ }^{6}$

The most important overview of this period in the Caribbean is a collected volume edited by Karen Eccles and Debbie McCollin, World War II and the Caribbean, published in 2017. The chapter "European Refugees in the Wider Caribbean in the Context of the Second World War" by Christian Cwik and Verena Muth might be the first attempt to estimate the number of refugees in the entire Caribbean area. Their literature-based estimates, ranging from 24,000 to 28,000 refugees, are very rough, and the authors report many statistical difficulties. To name a few, it is unclear whether these numbers include non-Jewish family members and if other groups such as escapees of the Spanish Civil War or deported prisoners of war are included. ${ }^{7}$ The refugees who fled Nazism and arrived in the Caribbean are also studied in other fields. They serve as one of the starting points for Sarah Phillips Casteel's intriguing Calypso Jews. ${ }^{8}$ Her monograph traces representations of Jewishness in Caribbean literature and poetry and has a historical reach from 1492 to the postwar era.

\section{Three Recent Monographs}

American historian Megan Koreman's The Escape Line refutes many assumptions about European resistance during the war with her detailed account of the Dutch-Paris resistance line that ran from the Netherlands to Spain and Switzerland. Canadian historian Eric Jennings's Escape from Vichy is a pioneering work on the government-endorsed flight route between Marseille and Martinique, which explores the lasting impact of encounters between refugees and Caribbean thinkers. British academic and current secretary general of the Association of Commonwealth Universities, Joanna Newman, contributes to the understanding of the role of the British West Indies in receiving war refugees from Europe and their interaction with international aid organisations in her Nearly the New World. 
All three authors demonstrate how transnational perspectives can deepen our understanding of the Second World War and its long-resonating effects. Their transnational perspective on flight movements preceding and during the war brings out similarities with current patterns and issues of flight and migration. As today, those refugees were not moving to a certain country when they fled occupied territory, they were first and foremost just leaving their homelands. Most of them had no clear plan, nor did they know where they would end up. This original ambiguity is often lost in historical research because the outcome is known and used as a reference point from which to look back on the migration. Researching their trajectories and agency enables a better understanding of the refugees' experience.

Megan Koreman researched the Dutch-Paris line, a transnational network of resistance that stretched from the Netherlands to Spain and Switzerland for The Escape Line: How the Ordinary Heroes of Dutch-Paris Resisted the Nazi Occupation of Western Europe. Her decade of research draws from over thirty archives across Europe and the United States. She published a book in Dutch about this resistance network in 2016 with (among other small adaptions) a different introduction and conclusion. ${ }^{9}$ The introduction to the English monograph is tuned towards an academic public, while the Dutch version caters to a more general audience. Koreman meticulously shows how the Dutch-Paris line was established by the French-Dutch businessman Jean Weidner and functioned between 1942 and 1944. The book is a group biography of the more than three hundred women and men who made this line possible. She explains not only how and when people joined the Dutch-Paris line, but also what motivated them to cross the boundary of civil disobedience. Herewith she creates the stage for the "ordinary heroes" of her title: they were not trained to do this work and came from diverse socioeconomic backgrounds, but were joined in risking their lives to help others. These resistance fighters smuggled food, coupons, and microfilm across borders and also opened their homes to refugees and assisted their passage.

After the chapters on establishing the line, Koreman also discusses the network's collapse, and the effect of the arrest of one of the couriers, Suzy Kraay. Severe physical and mental torture by the Germans resulted in Kraay giving up names and addresses of her fellow members in the Dutch-Paris line, which meant the end of it. Weidner did not blame her, she had not given information within the first day, which was the rule of thumb among resistance fighters in order to buy time. Koreman describes in great detail in chapter 6, "Catastrophe in Paris," how this last phase unfolded and what kind of safety measures Weidner had in place. In the final chapter, "Waiting for News," it becomes painstakingly clear how exceptional it was that so many members of the line survived. Even though many resistance fighters of the Dutch-Paris line got through the war, very few left a documented testimony. According to Koreman, they either were ashamed that they had not done more, or they thought their standing up against the Germans was merely an ordinary act of good citizenship.

Throughout Koreman's monograph gender is a factor: although the leaders of the line were all male, she keeps an eye on all the female resisters too. She explains how women were more suitable for some of the tasks and could move more freely during the last war 
years. Koreman illustrates this with the case of Johanna van Helden-Hus, a young widow from The Hague. In 1943 she was not allowed to assist the Belgium part of the network, because this work was supposedly too dangerous for women, although women, right from the start, played a significant role in other parts of the Dutch-Paris line. In 1944, this section of the network had no other choice than to accept help from women, since the streets of Brussels were too dangerous for men of military age, and Van Helden-Hus took care of thirty families in hiding. ${ }^{10}$ By making women's various roles explicit a shift in focus occurs: women were "not only" taking care of refugees in hiding but were also smuggling papers, food, and information across borders.

As most resistance activity occurred on a local scale, most scholarly work on resistance is also predominantly bounded by a local lens. From the perspective of researchers this is understandable: finding archival material about resistance is already challenging, and researching transnational contexts adds organisational and language problems. Koreman, however, researched archives scattered over Europe and America and found that this particular resistance network was actually quite well documented. The Weidner Center Archives (now the John Henry Weidner Papers, Hoover Library \& Archives at Stanford University) which came into existence as a result of Weidner's postwar work of archiving, were essential to this work. The archive contains, among other things, reports of trips, lists of the rescued Allied aviators, and carbon copies of Weidner's correspondence, which Koreman uses extensively.

Koreman's work, enriched with many of these untapped sources, is valuable for its great level of detail, through which she uncovers many new aspects of resistance during the Second World War. This amount of detail, however, also might overwhelm the reader, as she introduces so many cogs in the wheel of the Dutch-Paris line. The reader could lose track of the numerous individuals, many afforded a personal background and motivation, and the many small events in various places along the network. Her descriptive style, delving into the many various contexts that explain these events and characters, makes it difficult to understand the personalities and motivations of the few leaders and creators of the Dutch-Paris line, even though they, and especially the architect of the line, Jean Weidner, and his wife, Elisabeth Cartier, are portrayed at greater length. A bigger, related issue is that the book seems to lack a main overarching question. Koreman's meticulous research could support many convincing arguments about this history; however, the argument tends to get lost in an overabundance of detail.

One of Koreman's principal arguments, made in the first half of the book, is to show the importance of locally based networks of resistance for the functioning of a bigger international line. She gives a good example in the third chapter: the positive effect of the cooperation between Weidner's group and the already active Comité tot steun voor Nederlandsche Oorlogsslachtoffers (Committee in support of Dutch war victims). The work of the Comité was to help Dutch war victims in Belgium and it was structured into two separate branches: sociaalwerk or "social aid," meaning the support of Jewish refugees in hiding, and transportwerk or "transport," helping refugees escape in the direction of unoccupied parts of Europe. The Dutch-Paris line incorporated this structure and later added a third separate intelligence line. The few members of the 
Dutch-Paris network working for this last line smuggled microfilm containing information about civilian life under occupation as well as copies of underground newspapers from the Netherlands to Switzerland. Without these local structures the Dutch-Paris line would not have been able to help the estimated 1,500 people in hiding and help another 1,500 to reach Switzerland and Spain (26). The reader, however, needs to deduce this conclusion from the implicit well of information.

Notwithstanding the high quality of her research, at several instances there are hints of a darker or less heroic side of this resistance network which remain underexplored. There are mentions of theft and unreasonably high prices demanded by passeurs, guides who passed refugees over the borders illegally. These passeurs are portrayed as not actual members of the Dutch-Paris line, but rather as professionals Weidner was forced to hire. This raises the question: what defines an official member of an unofficial organisation operating in the shadows of several regimes (135)? Koreman briefly mentions a civil lawsuit against Weidner, which he refused to fight in order to protect Kraay. But we never learn who started the lawsuit and why (212). Delving into the darker or even ambiguous aspects of this network would have added depth to the analysis. Perhaps Koreman was reluctant to do so because this might hurt Weidner's reputation. This seems to be in line with her tendency towards hagiography of the "ordinary heroes" and their leaders. In the interest of full disclosure, Koreman herself states that the John Weidner Foundation for Altruism has co-financed the research and receives half of the book's proceeds (xi).

Koreman highlights how unique the Dutch-Paris line was: it operated "across four borders and two mountain ranges, using five currencies and three languages in six occupied zones, each of which required different identity documents and travel passes" (263). She even mentions contact between the Dutch-Paris line and other networks of resistance, a topic that deserves further exploration. She however does not expand on her important contributions to the field. Nor does she reflect on how her research sheds new light on resistance during the Second World War. The operation was much more advanced than previously recognised, and she contributes valuable insight into the day-to-day experience of resistance throughout Europe. A more defined engagement with the existing literature and debates would add broader relevance to this monograph.

In Escape from Vichy: The Refugee Exodus to the French Caribbean, Eric Jennings shows the multifaceted origin and effect of the migration through the short-lived corridor between Vichy-governed Marseille and Martinique. This monograph adds to his impressive bibliography, which already spans five continents, and helps to decentre and globalise the history of France. Even though the route was open only between roughly June 1940 and May 1941, it saved several thousands of lives (45-48). This was partly thanks to the help of aid organisations; here, in particular, the Emergency Rescue Committee helped with visas. In this case not only Jewish refugees were saved, but also many French artists and critics of the regime, and Spanish Republicans. Jennings skilfully combines the political background of the corridor with the cultural aspects of the refugees' arrival. As in his earlier work (for example, his 2001 Vichy in the Tropics), Jennings draws from an enormous amount of archival material and memoires, which he aptly contextualises in the broader scholarly debate. The book is structured along two almost 
separate lines of freestanding chapters: in chapters 1, 2, 5, and 8, Jennings chronologically sketches the historical context, while he centres chapters 3, 4, 6, and 7 around the refugees and their experiences. It is clear that his interest lies mainly in the second line.

The first line sketches the context. In the first chapter the emigration policies of Vichy France are explained, and Jennings describes the dire situation of the refugees in both the occupied and unoccupied French mainland between 1938 and 1942. He shows how hard it was to leave Vichy France and how policy shifts during the beginning of the war made leaving even harder. In the second chapter Martinique emerges as one of the very few escape routes out of Europe that was government endorsed. Right from the start the motivation of the Vichy regime was a curious mix of xenophobia and scapegoating on one hand and a vague sense of humanitarianism on the other. Due to the bad conditions on board the ships some refugees were uncertain as to whether they were exiled by their government or had escaped from it. The governor of Martinique was also unhelpful: he complained that these refugees could not pay for their own internment (50).

Chapters 5 and 8 delve into the political context in which the corridor existed and later was closed. The fifth chapter sketches the wartime Martinique society in which the refugees arrived; it was divided both by race and by class. Jennings also describes the array of reactions towards the newcomers, some provoked by rumours about scarcity of food and clothes. Chapter 8 explains how the Martinique corridor ceased to exist. Due to the structure of freestanding chapters, some repetition occurs throughout the book. Despite repeated references to the Dutch ship Van Kinsbergen, for example, which was involved in ending the corridor, the reader has to wait until page 219 to find out what actually happened. (In a nutshell, the Allied forces suspected that German spies were hiding in the midst of the refugees on the Winnipeg. When the sailors of the Van Kinsbergen boarded they expected to find over two hundred pro-Nazis, but instead found only refugees fleeing the Nazi regime.)

In the second line of chapters Jennings foregrounds the refugees' experiences during their flight out of Vichy France. In chapter 3, "Understanding the Martinique Route," he portrays individual stories of foreign and French refugees who were directed to or stumbled upon the Martinique route and their encounters with bureaucracy. Not all Vichy administrators executed the same policy in the same manner, a circumstance that some of the refugees were able to use to their advantage. From these personal stories we learn that not only the more common aspects, such as money, luck, and courage, but also social networks, rumours, and serendipity played a significant role in finding a way out of Europe. In the fourth chapter, "The Crossings," Jennings turns to the actual flight and skips the bureaucracy and the waiting for visas to focus on the experience of being aboard the ship that carried the travellers away from war-torn Europe. He elaborates on food, pastimes, the stopover in Casablanca, and the traditional festivities marking the crossing of the Tropic of Cancer. His descriptions of the interactions and activities of the refugees reemphasises how well educated the average passenger was. Jennings briefly delves into what kind of cargo was on board: namely, food that was shipped from Morocco to Martinique and from Martinique to France (112-113). At the end of this article, I will come back to both these chapters, to discuss whose voices are foregrounded here. 
In the sixth chapter, "Snakes Charmers in a Viper's Nest," Jennings discusses the period that the refugees spent on the island and reveals the structural tension between occupied France, Vichy France, and the colonial administration. Jennings stresses the unpleasant arrival: the incoming refugees were interrogated, and the non-French refugees were called enemies while the French refugees were seen as cowards for leaving their country. The non-French refugees were interned in two camps and lived under the threat of being sent back to their port of departure. Jennings elaborates on the circumstances in the internment camps, which some refugees referred to as a "concentration camp." The chapter is richly illustrated with pictures made by the refugee Germaine Krull, who was able to smuggle her camera into the camp, and by paintings by two other refugees. The encounters between the inhabitants of Martinique and the refugees are diverse; while lasting friendships were made, there were also Martinicans who refused to sell products to Jewish Germans.

The most important contribution to the wider field of Caribbean studies is chapter 7, "Surrealism Meets Negritude," in which Jennings describes a previously neglected but fruitful encounter that happened because of this corridor. Surrealist painter André Breton stumbled upon the first issue of the local journal Tropiques, dating from April 1941, surprisingly in a haberdashery. According to Jennings, "as he cracked open the journal, epiphany struck": in contrast to contemporary French publications, here the Vichy government was openly criticised (180). Via the shopkeeper, the sister of the Martinican philosopher René Ménil, Breton was soon introduced to the thinkers behind Tropiques, including Aimé and Suzanne Césaire. The Césaires would become among the most important and widely read authors of the Caribbean, especially on colonialism. Breton and some other refugees formed a small group with the Tropiques people, and they sat discussing in cafes for hours and went on day-long hikes together. Of the various refugees, it was mainly the French artists who interacted with the local Caribbean intellectuals. This was partly, as Jennings explains, because the non-French (mainly Jewish Germans and Spanish Republicans) were interned. A second explanation could also be the common language. Jennings's convincing analysis in this chapter of the impact of these encounters on both the Negritude intellectuals and the Surrealist painters would in itself make the entire work a valuable contribution to World War II and Caribbean studies, demonstrating how a transnational perspective can show the long-resonating effects on both sides of such encounters.

In Nearly the New World: The British West Indies and the Flight from Nazism, 19331945, Joanna Newman explores the arrival of European refugees in the British West Indies. Her book is structured in three chronological parts, with the first, "Introductions," providing the context for the next two parts, "Confronting the Need for Refuge" and "Confronting the Need for Rescue." Part 1 centres on European countries that denied Jewish refugees entry to their territories. She also delves into migration to the British West Indies up to 1939. Newman shows in the second part of her book how people did manage to leave Europe, mainly through the help of aid organisations, and what happened to them when they arrived in the British West Indies. Her focus throughout the book is on the prewar period and on the first two years of the war. 
The introduction opens with a discussion of the contextual drivers: an overview of Jewish presence in the Caribbean and the impact of the Second World War on the region. Newman recounts existing scholarly debates about the creolisation and incorporation of Jewish people in Caribbean societies, for example Jamaica. In reviewing immigration policies, she shows that Jamaica, Barbados, and Trinidad tightened immigration rules from 1933 onwards. This same restrictive tendency is discussed by Jennings for the French territories. Another topic in this section are the Jewish aid funds. Newman describes how they came into being and how they differed "not only in political orientation but also in political practice," which would come to overshadow the organisations' collaboration in the 1940s (48).

The need for refuge is dealt with in the following two chapters: "Jews Seeking Refuge, 1933-1938" and "Panic Migration: The British West Indies and the Refugee Crisis of 1938-1939." The former portrays the flight of mainly German Jews and the latter the reaction of the British government and colonial administrations to the influx of refugees. The international debate about the crisis culminated in the Evian Conference of 1938, which aimed to solve the Jewish refugee problem but was internationally seen as a failure. From the perspective of the Colonial Office, though, it was a success: the West Indian colonies were not mentioned as a potential solution to the crisis and the British Mandate for Palestine only on the last day. The British emphasis remained on the refugees that were already in British territories and therefore little forethought was given to assisting refugees that might come in the future. As the numbers of Jewish fugitives increased and the possible options for escape decreased, the British colonies slowly emerged as a possible site of refuge. The governors and colonial administrations did everything in their power to avoid welcoming Jewish refugees in their territories. This chapter also highlights the heterogeneity of the groups of refugees, who were of different socioeconomic backgrounds and religious identities.

Part 3 opens with the chapter "Boat People." Contrary to what the title suggests, it is not as much about individuals as it is about policy and the fate of entire groups of refugees. Newman does not mention that "the groups" in this chapter were so heterogeneous that they did not even perceive themselves as a group. Although their fate was bound by the destiny of a particular ship, their experiences of the flight, the crossing, and especially the arrival varied greatly. Newman also elaborates on ships with refugees aboard that were not bound for the British West Indies, for example the well-known case of the St. Louis. The refugees on this ship were the victims of different political manoeuvres and, in the end, were sent back to Europe, where many of them perished. The St. Louis would function as a feared reference point for later refugees crossing the North Atlantic Ocean.

The final chapter, "Internment Camps and Missed Opportunities," sketches the stay of the refugees in the British West Indies, with a strong focus on those living in Trinidad and Jamaica. For the latter, Newman aptly refers to Diana Cooper-Clark's Dreams of Re-Creation in Jamaica, which recounts the refugees' day-to-day life in Gibraltar Camp. Another central topic is the Bermuda Conference of 1943, which again discussed the question of Jewish refugees, and its international consequences for the refugee crisis. 
In this chapter Newman also relies heavily on sources from American archives, mainly documents of American aid organisations and a few self-published memoires. Unfortunately, this limits the view of the daily life of the refugees in the Caribbean. More importantly, the focus on the aid organisations' sources results in a contorted view of history by at times mistaking the plans of these aid organisations for actual events. For example, Newman miscalculates the number of refugees who arrived in the Dutch Caribbean colonies, as she counts the intentions of the aid organisations rather than the actual arrivals (212).

Although Newman is aware that "the different parties involved obviously had strong reasons for portraying life in the internment camps in varying ways," (194) she does not seem to maintain this caution throughout her analysis. On many occasions the view of the aid organisations prevails and often there is a lack of a local Caribbean perspective. Even though she explicitly states in her introduction that a comparison of the different camps lies beyond the scope of her research, even a superficial comparison would have added much more insight into the situation of the refugees. Newman mentions that there were vast differences between the different camps within and between colonies, but leaves unanswered questions like what kind of differences, what did they mean for the refugees, and how did they come into being? Likewise, the work barely touches on the interactions of the refugees with the locals or the (local) Jewish community.

In the epilogue Newman deals with when and how the refugees left and why a small number of them stayed. The threads of experiences of refugees who were present in the introduction and woven throughout the book only fully resurface here, be it only of three male refugees. In the core of the monograph, individual stories take a background status to a foregrounded emphasis on governmental policy and aid organisations. Nevertheless, this book, drawing from previously unused archives, systematically describing a refugee trajectory heretofore overlooked, and demonstrating the effects of anti-Semitism far beyond Europe, is an important contribution to refugee studies, Caribbean studies, and World War II studies.

\section{Problems in Sources and Perspectives}

An important conclusion in Newman's book is that the Jewish Refugee Organizations (JROs), despite their vast differences, were of more importance in saving Jewish lives during the Second World War than previously acknowledged. She shows how among others the American Jewish Joint Distribution Committee (the JDC or "Joint"), Hebrew Sheltering and Immigrant Aid Society (HIAS), and the World Jewish Congress did play a significant role in creating the Caribbean flight routes. These organisations contacted governments, stood surety for the refugees, and helped them with their paperwork, money, and shelter. Sometimes even the aid organisations underestimated their role, as happened for example in the case of the refugees on the St. Louis. The JDC's negotiator in Havana, handicapped by his own immense optimism, was too positive about the diplomatic situation; in the end the St. Louis was denied entrance to Cuba and sent back to Europe. 
Because Newman's research is predominantly based on sources from these aid organisations, they naturally foreground the relevance of the organisations in which they were produced. Her source selection might have influenced the weight she gives to the aid organisations in organising the flight. Additionally, Nearly the New World lacks a Caribbean perspective. Newman uses virtually no archival material from the Caribbean: only six calypsos, songs that functioned as critiques of the current developments in Trinidadian society, with which she interprets the public mood in the British West Indian societies towards the refugees. Although these songs do contribute to a better understanding of the reception of the refugees in Trinidad, as a source they do not answer the question fully; calypsos were political pamphlets or news outlets, not descriptions of day-to-day encounters. Moreover, these calypsos were specific for the Trinidadian context and tell us very little about the situation in Jamaica or the rest of the British West Indies. In this case the lack of Caribbean sources leads directly to the lack of Caribbean perspectives and voices.

Escape from Vichy has similar problems: although Jennings does use sources from the Caribbean, he only refers to Western sources in describing the day-to-day interactions of the European refugees with ordinary Martinicans (173). The societies that received these refugees were not empty canvasses. They had a highly complicated colonial past that directly influenced their contact with and position towards the refugees, which subsequently had impacts on the refugees' experience. By not doing justice to the complexity of the receiving Martinican society, Jennings paints a one-sided portrait, even if his focus was only the experience of the refugees. In separate chapters he does write about the Martinican war context, but he neglects this perspective in describing personal encounters. During my research on the mainly Jewish refugees who arrived in Suriname in December 1942, Surinamese Jewish sources turned out to be essential in understanding the interaction of refugees with the local Jewish community and their position within the broader Surinamese society. I found that the interactions frequently appeared in the minutes of the endless meetings of, for example, the Ashkenazi board and Surinamese Zionist Society, but also many refugees sent letters themselves to these boards with complaints or requests on diverse topics, ranging from housing problems to religious concerns. $^{11}$

Despite Jennings's combination of a wide variety of sources, his perspective on the history of the Martinique corridor remains focussed on the elite refugees. He explains that the Emergency Rescue Committee concentrated its "efforts on European artists, writers, politicians, scientists, and scholars," (14) and he mentions that it made a selection among the refugees in Marseille, but he does not explain how or by what criteria. It is unclear how many refugees found the corridor without help and whether that group came from a different socioeconomic background, although the book includes multiple references to these non-famous refugees who also fled to Martinique. In reading chapter 4 about being on board the ships, many questions linger. For example, who were the "series of young people of all nationalities" (84) that were aboard the Paul Lemerle? And who visited whom in the port of Casablanca and who bought goods or services there, and from whom (115)? What did the people who were excluded from the card games 
do to pass time on the ship (90)? These ships were meant for cargo, so where did the refugees sleep, how were their sanitary fittings arranged, and were these arrangements dependent on one's wealth? Although educated refugees are likely to leave more traces, it is hard to imagine that it would have been impossible to go beyond only briefly referring to the great number of other refugees. And if it was Jennings's goal to solely portray the artists and their interaction with Caribbean thinkers, he could have made this more explicit from the start. In either case this book did not turn out to be a "biography of their collective escape" to Martinique (1).

The final aspect of the source selections is agency: none of the three monographs attribute much agency to the refugees who fled war-torn Europe, and thus end up obscuring an important aspect of the refugees' flight and experience. A partial explanation is Jennings's and Newman's policy-centred approach: both pay attention to the internal tension between the colonial administrations and their European governments (and in the French case also between occupied France and Vichy France). Newman, as mentioned before, studied how the aid organisations interceded with policy. For Jennings, the cultural influence of the corridor on art and philosophy is an important perspective. Both approaches, however, pass over the agency of the refugees: their own role in their escape and subsequent fate. Another part of the explanation for this omission is again source selection: to analyse agency, it is necessary to have access to contemporary sources often of a private nature. Koreman does pay attention to individual agency, but emphasises the agency of resistance fighters, seldom that of the Jewish refugees. In contrast to Newman and Jennings, however, Koreman does not claim to write about the refugees.

To conclude, the authors' source selection leads them to portray only a small segment of the actors involved in this trajectory. Newman, for example in her epilogue, uses mostly male examples to delve into the refugee experience. It is obvious that these experiences could be very different for women, with or without children. In the Neve Shalom Archive in Paramaribo I found a small notebook, dating from the 1940s, containing the accounting of a fancywork class for young girls. Their bookkeeping detailing fairs and handiwork gave insight into the day-to-day life of the escaped women and young girls. ${ }^{12}$ Jennings's monograph has similar issues; he for example, does not explicitly justify the selection of particular foregrounded individuals in his third chapter, although the stories he chooses to highlight are those of highly educated refugees and often socialists or communists. Both monographs might have benefitted from considering intersectionality as an analytical framework, which would help to understand the intertwining of class, race, gender, religion, age, and nationality in various refugees' journeys. It might also have made it possible to strengthen the Caribbean perspective and show its impact in the experience of the European refugees. As mentioned, Koreman seems more sensitive to the resistance fighters' socioeconomic background and their family situation, moreover she names multiple women working for the Dutch-Paris line.

Taken together, Escape from Vichy, The Escape Line, and Nearly the New World include a wealth of new information and unused sources. At the same time, they demonstrate the main challenge in this emerging field of transnational research of the Second World War period: the finding and subsequent selection of sources, which leads to the 
selection of voices and perspectives. These monographs uncover previously neglected aspects of the trajectories of refugees during the Second World War and unveil several new actors: international resistance networks, aid organisations, and colonial administrations. These monographs reveal the similarities in patterns and issues of current migration movements and allow us to develop new methods in researching flight migration. Therefore, these monographs will be eagerly used in future research.

\section{Acknowledgements}

My $\mathrm{PhD}$ is funded by the PhDs in Humanities grant of the Dutch Research Council (NWO). I would like to thank Ward Berenschot (KITLV), Simone Casale (KITLV), Emily Hansell Clark (Erasmus University Rotterdam), Rosemarijn Hoefte (KITLV), Joseph Sony Jean (KITLV), David Kloos (KITLV), and Peter Romijn (NIOD) for commenting on earlier drafts.

\section{Bibliography}

\section{Published Secondary Sources}

Casteel, Sarah Phillips. Calypso Jews: Jewishness in the Caribbean Literary Imagination. New York: Columbia University Press, 2016.

Cooper-Clark, Diana. Dreams of Re-Creation in Jamaica: The Holocaust, Internment, Jewish Refugees in Gibraltar Camp, Jamaican Jews and Sephardim. Victoria: FriesenPress, 2017.

Cwik, Christian, and Verena Muth. "European Refugees in the Wider Caribbean in the Context of World War II." In World War II and the Caribbean, eds. Karen E. Eccles and Debbie McCollin, 247-72. Kingston: University of the West Indies Press, 2017.

Ditzhuijzen, Jeannette van. A Shtetl under the Sun: The Ashkenazic Community of Curaçao. Amsterdam: KIT Publishers, 2011.

Eccles, Karen E., and Debbie McCollin, eds. World War II and the Caribbean. Kingston: University of the West Indies Press, 2017.

Horst, Liesbeth van der, ed. Wereldoorlog in de West: Suriname, de Nederlandse Antillen en Aruba 1940-1945. Hilversum: Uitgeverij Verloren, 2004.

Jennings, Eric T. Escape from Vichy: The Refugee Exodus to the French Caribbean. Cambridge, Mass.: Harvard University Press, 2018.

- Vichy in the Tropics: Pétain's National Revolution in Madagascar, Guadeloupe and Indochina, 1940-1944. Stanford, Calif.: Stanford University Press, 2001.

Jong, Loe de. Het Koninkrijk der Nederlanden in de Tweede Wereldoorlog, Deel 9, eerste helft. Den Haag: Martinus Nijhoff, 1979.

Kaplan, Marion A. Dominican Haven: The Jewish Refugee Settlement in Sosúa, 1940-1945. New York: Museum of Jewish Heritage, 2008.

Koreman, Megan. The Escape Line: How the Ordinary Heroes of Dutch-Paris Resisted the Nazi Occupation of Western Europe. New York: Oxford University Press, 2018.

- Gewone Helden: De Dutch-Paris ontsnappingslijn 1942-1945. Amsterdam: Boom, 2016.

Levine, Robert M. Tropical Diaspora: The Jewish Experience in Cuba. Gainesville: University Press of Florida, 1993.

Newman, Joanna. Nearly the New World: The British West Indies and the Flight from Nazism, 1933-1945. New York: Berghahn Books, 2019.

Scholtens, Ben. Suriname tijdens de Tweede Wereldoorlog. Paramaribo: Anton de Kom Universiteit van Suriname, 1985. 


\section{Notes}

* PhD candidate at the University of Amsterdam (UvA); guest researcher at Royal Netherlands Institute of Southeast Asian and Caribbean Studies (KITLV) and at the Institute for War, Holocaust and Genocide Studies (NIOD).

1 Kaplan, Dominican Haven.

2 Levine, Tropical Diaspora.

3 Cooper-Clark, Dreams of Re-Creation in Jamaica.

4 De Jong, Het Koninkrijk der Nederlanden.

5 Van der Horst, Wereldoorlog in de West.
6 Ditzhuijzen, A Shtetl under the Sun; and Scholtens, Suriname tijdens de Tweede Wereldoorlog.

7 Cwik and Muth, "European Refugees in the Wider Caribbean."

8 Phillips Casteel, Calypso Jews.

9 Koreman, Gewone helden.

10 Koreman, The Escape Line.

11 I continue this research in the NWO funded $\mathrm{PhD}$ project "From European Ports to Caribbean Homes."

12 Neve Shalom, Paramaribo, Suriname, "Handwerkklasje." 